Stephen Cranney

\title{
Judicial Dictatorship: Potential Institutionalisations of the Constitutional Review Process
}

\author{
Faculty of Law
}

Victoria University of Wellington 
Table of Contents

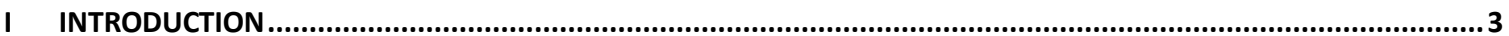

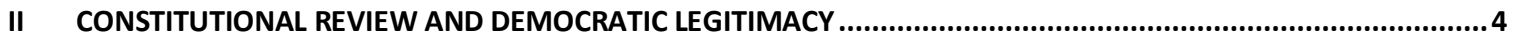

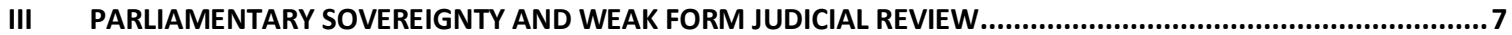

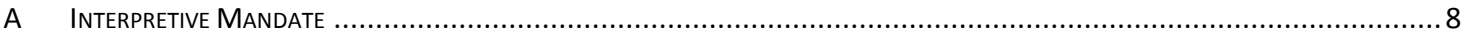

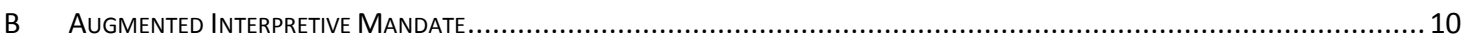

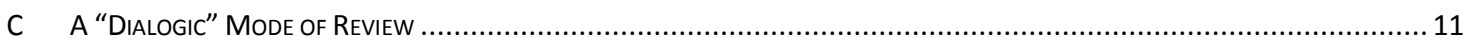

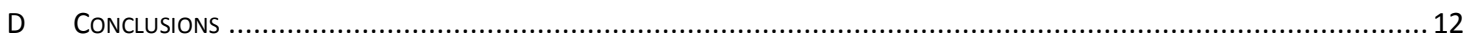

IV DEGENERATION AND EVOLUTION OF WEAK FORM REVIEW ................................................................

A Evolution into Effective Strong Form Review ...................................................................... 12

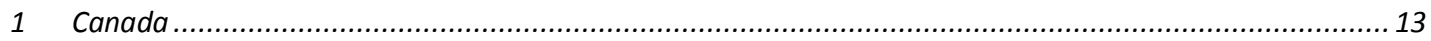

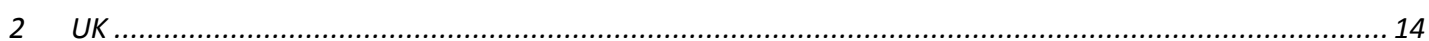

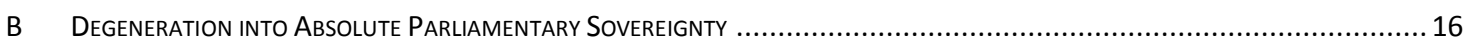

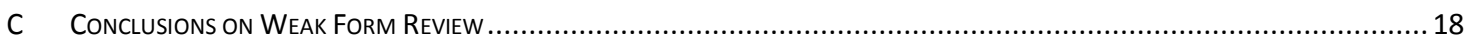

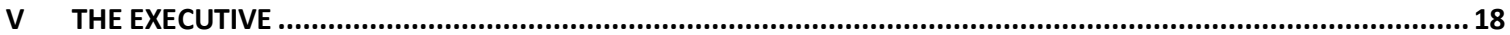

VI POTENTIAL INSTITUTIONALISATIONS OF THE CONSTITUTIONAL REVIEW PROCESS ........................................20

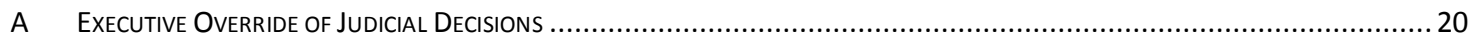

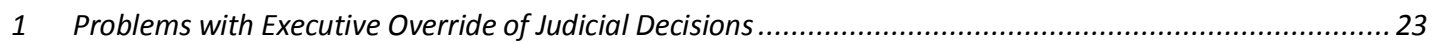

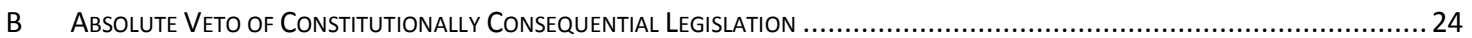

1 Problems with Absolute Veto of Constitutionally Consequential Legislation ...........................................2 27

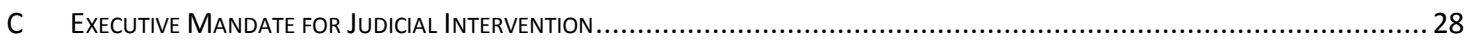

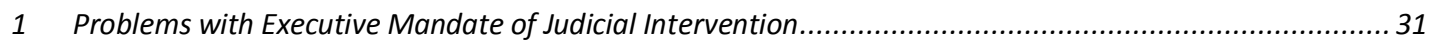

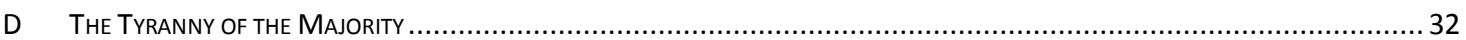

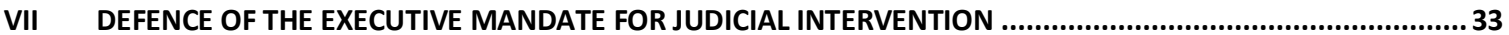

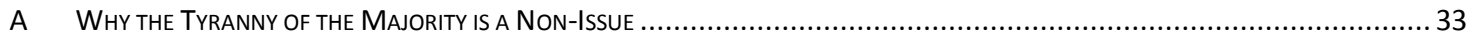

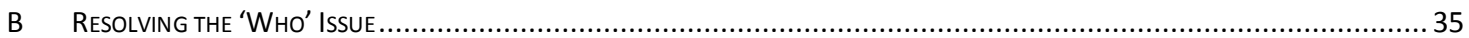

C Executive Mandate for Judicial Intervention as the Dominant Proposed Mechanism .......................................... 36

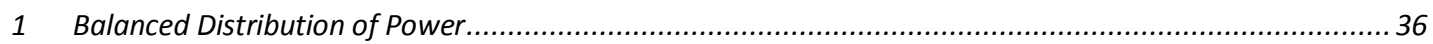

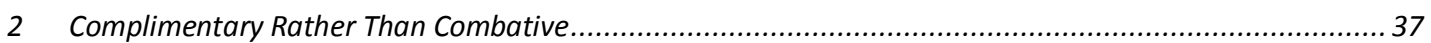

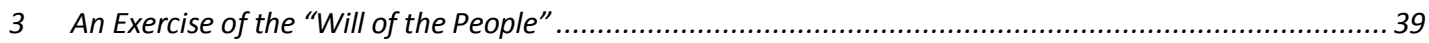

VIII CONCLUSION.................................................................................................................40

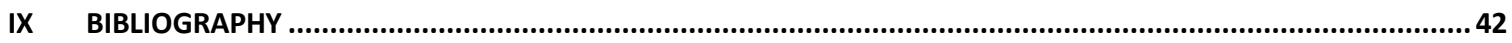




\begin{abstract}
This paper concerns constitutional review of legislation, a widely discussed issue within comparative constitutional law. Specifically, this paper addresses the issue of the lack of democratic legitimacy that U.S. style judicial review has and the potential lack of stability that other weak form constitutional review mechanisms have. Three constitutional review procedures are proposed in this paper, with the commonly overlooked executive branch playing a central role in each review mechanism. These proposed procedures aim to solve democratic legitimacy and stability issues. While all three arguably accomplish the mentioned goal, the paper addresses the issues each proposed mechanism has before defending the leading mechanism. The paper offers a possible solution to the seemingly unresolvable tension within constitutional review of parliamentary sovereignty and judicial supremacy. The described mechanisms and the outcomes they produce seems to show that democratically based constitutional review is possible and it is not necessary to rely on unelected judges to ensure that constitutional rights are maintained. Ultimately, this paper aims to show that a redistribution of constitutional review power among all state organs is the best way to ensure that legislation conforms to constitutional norms.
\end{abstract}

\title{
I Introduction
}

"We the People." One of the most emotion evoking and potentially over used statements has found its way to the center of many democracy-based arguments in constitutional analysis. But if the 'people' are center to democracy and the social contract that democracy constructs, then how is it that their voice has become irrelevant? This paper explores different methods of constitutional review, with an attempt to find a more democratically legitimate decision making process. It asks whether the executive branch of government should be given the task of determining the consistency of legislation with constitutional norms, including a bill of rights. Ultimately this paper argues that the underutilized organ of the executive can be employed to legitimise and solve many of the issues surrounding the constitutional review power that currently lies with the courts.

The paper begins by explaining the type of decision-making process referred to as 'constitutional review' and discusses the potential lack of democratic legitimacy that this process can have. The paper then discusses how commentators who oppose judicial review rely on ideas of parliamentary supremacy or 'weak form' constitutional review to try answer judicial review critiques. By examining three types of weak form constitutional review, we see that these processes have democratic legitimacy but have potential stability issues, seen by examples in the UK and Canada. The paper moves on to introduce the executive branch and argues that this body has an equal mandate in the constitutional review process before presenting potential executive based constitutional review procedures. 
The paper proposes three review mechanisms. Firstly, an executive override of judicial decisions, where the executive branch can return a piece of legislation that has been struck down to legal effectiveness. Secondly, a veto of constitutionally consequential legislation, where the executive can render a piece of legislation legally ineffective, coupled with an inability for a legislative override. Lastly, an executive mandate for judicial intervention, where the executive informs the judiciary which pieces of legislation can potentially be struck down. The paper expands of these descriptions, discussing potential problems that these methods face before finally defending one decision-making process. By this, the paper aims to satisfactorily create a stable and democratically legitimate constitutional review procedure.

\section{Constitutional Review and Democratic Legitimacy}

Constitutional review is the inquiry and decision of whether a piece of legislation is consistent with a country's constitutional norms. For the purposes of this paper, constitutional review should be understood as this wide meaning, completely excluding the body or method in which the inquiry and decision is arrived at. However, judicial review for the purposes of this paper should be understood slightly differently. Judicial review, which will be mentioned frequently, refers to the 'strong form' judicial review described by Mark Tushnet and as seen in the US. According to Tushnet, strong form judicial review is where the courts have general authority to determine the meaning of the constitution and more importantly, the courts' constitutional interpretations are authoritative and binding on the other branches of government. ${ }^{1}$ In the absence of a constitutional amendment, the court's decision is final in the case of judicial review; legislation can be declared invalid and 'struck down' by the courts. This paper will mainly be focusing on the issues surrounding this type of judicial review.

It is said that judicial review requires at least three conditions for it to function within a constitutional system: ${ }^{2}$

(1) It requires the existence of a written constitution, which is conceived as a superior and fundamental law with clear supremacy over other laws;

\footnotetext{
1 Mark V. Tushnet "Alternative Forms of Judicial Review” (2005) 101 Georgetown Law Faculty Publications and Other Works 2781 at 2784.

2 Danielle E. Finck "Judicial Review: The United States Supreme Court Versus the German Constitutional Court” (1997) 20 B.C Int'l \& Comp. L. Rev. 123 at 125.
} 
(2) The constitution must be of a rigid character; the amendments or reforms that may be introduced can only be put into practice by means of a particular process ${ }^{3}$; and

(3) The constitution must establish the judicial means for guaranteeing its supremacy over legislative acts.

When a country has all three of these conditions satisfied, judicial review of legislation obtains the highest amount of legal supremacy and judges, as agents of the judiciary, obtain the highest amount of constitutional power. Of course any appropriately enacted constitutional amendment that alters the above conditions will have the potential to change or strip the judge's power, but in the absence of such a constitutional amendment, the judiciary is supreme.

This power given to the courts, of the judicial review of legislation, involves a group of people who seemingly enjoy no political legitimacy and certainly no democratic legitimacy to impose their preferences on citizens generally. ${ }^{4}$ The judiciary's decisions work to thwart policies of the democratic branches of government. ${ }^{5}$ The individuals who strike down the legislation are both unelected and unaccountable. What they are effectively doing is invalidating democratically adopted laws. ${ }^{6}$ The question must be asked of how this role can be justified in a system that is based on the view that policy and value choices are for the elected and politically responsible institutions. ${ }^{7}$

Jeremy Waldron has looked closely at the above stated question, undertaking an analysis of the democratic legitimacy of judicial review. Prior to his inquiry, he creates context. Waldron describes the type of society in which his examination operates within. His assumptions are, firstly, that the society has democratic institutions in reasonably working order, including a representative legislature elected in the basis of universal adult suffrage. ${ }^{8}$ Secondly, that there is a set of judicial institutions, again, in reasonably good working order, set up on a non-representative basis to hear individual lawsuits, settle disputes and uphold the rule of law. ${ }^{9}$ Thirdly, that there is a commitment on the part of

3 This particular process is more difficult than the one used for the adoption of ordinary legislation. For example, the process may require $75 \%$ of the available votes rather than a simple $50 \%$ majority.

${ }^{4}$ Daniel Markovits “Democratic Disobedience” (2004-2005) 114 Yale L.J. 1897 at 1929.

${ }^{5}$ At 1929.

${ }^{6}$ At 1929.

7 D. J. Galligan “Judicial Review and Democratic Principles: Two Theories” in Mark Tushnet Bill of Rights (Ashgate, Hampshire, 2007) 37 at 37.

${ }^{8}$ Jeremy Waldron "The Core of the Case Against Judicial Review" (2006) 115 Yale L.J. 1346 at 1360.

${ }^{9}$ At 1360. 
most members of the society and most of its officials to individual and minority rights. ${ }^{10}$ Lastly, that there exists persisting, substantial and good faith disagreement about rights among members of the society who are committed to the idea of rights. ${ }^{11}$ This paper relies on these assumptions and other assumptions that will be described later.

Democratic legitimacy is a term that needs explanation. It can be best understood by the example where Waldron discusses majority decisions. A person disagreeing with a decision may ask why they should be bound or burdened by the decision. ${ }^{12}$ The decision can be 'legitimised' through the process in which it was arrived at, meaning that a person who disagrees with the outcome of the decision can still accept the decision due to the legitimate means in which it was reached. ${ }^{13}$ A democratic decision, reached by a majority can be said to be more legitimate than an undemocratic decision. Waldron explains why this is so.

A citizen may ask why a group of people (the legislature) should have the right to decide a question of rights affecting them. Assuming elections to the legislature are fair, then the legislature is made up of people who were all treated equal to their fellow citizens in determining who should be privileged to make up the legislature. ${ }^{14}$ The people within the legislature are there due to winning a majority vote. Therefore, the legislature's decision, which is made by a majority of the legislature, is in theory a reasonable approximation of the decision that would be reached by the majority of citizens as a whole. ${ }^{15}$ So in fact, what we say is that even though the decision that affects the rights of an individual is made by the legislature, the process through which that decision is made, to a certain extent, lets all individuals make a decision on the matter. It is this process which makes the democratic decisions legitimate.

Contrary to this, Waldron looks at a decision involving rights that is made by the courts. Again, a citizen who disagrees in substance about a decision affecting her rights may ask why a small group of unelected men or women may determine this matter. ${ }^{16}$ A possible answer to this is that the judges are appointed by democratically elected decision makers

\footnotetext{
${ }^{10}$ Waldron "The Core of the Case Against Judicial Review", above n 8, at 1360.

${ }^{11}$ At 1360.

${ }^{12}$ At 1387.

${ }^{13}$ At 1387.

${ }^{14}$ At 1387.

${ }^{15}$ At 1387.

${ }^{16}$ At 1390.
} 
or decision making bodies (such as a president or a legislature) ${ }^{17}$ Because appointment stems from a democratically elected decision maker, the trickle through of democratic principles reaches the judges in a way to legitimise the process. But if legitimacy of process is a comparative matter, then the system of legislative decision-making must be superior. Although in reality the system of legislative elections and decisions is not perfect, it is evidently more superior as a matter of democracy and democratic values than the indirect and limited basis of democracy that the judiciary can be said to have. ${ }^{18}$ Legislators are at all times accountable to their constituents and their behavior is representative of the electoral credentials that were put forward and agreed with by the majority of voters when the voters accepted that person into the participation of political decision making. ${ }^{19}$ This is not true for judges. They are not accountable to any person or entity, and it is this factor within the judicial decision making process which can be said to place the nail in the coffin for any type of pretended democratic legitimacy that a judiciary can be said to have.

Based on Waldron's explanation of democratic legitimacy and the examples he gives, it is fairly clear that a decision affecting individual's rights which is made by the judicial branch of government has little legitimacy when compared to a decision made by a democratic and representative branch of government. If this is the case, then how have commentators responded to issues relating to judicial review of legislation?

\section{Parliamentary Sovereignty and Weak Form Judicial Review}

When constitutional review takes place, what we have are members of a society disagreeing about whether a piece of legislation violates an individual's rights. ${ }^{20} \mathrm{We}$ have one party saying that, in their opinion, legislation has infringed their constitutionally entrenched rights, whereas another party is saying, in their opinion, that the legislation does not restrict constitutional rights. In the case of potentially ambiguous legislation, this disagreement is completely reasonable and will need resolving. Judicial review of legislation is one method of resolving this disagreement. However, as explained above, this decision making process can be said to lack democratic legitimacy. What is needed is a decision making procedure in which members of society can agree with the legitimacy of the decision making process, even when they disagree about rights or the outcomes

\footnotetext{
${ }^{17}$ Waldron "The Core of the Case Against Judicial Review", above n 8, at 1391.

${ }^{18}$ At 1391.

${ }^{19}$ At 1391

${ }^{20}$ At 1371.
} 
that the decision making process produces. Commentators addressing judicial review of legislation have suggested other methods of resolving constitutional disagreements that are potentially more democratically legitimate and which leave the final say of a statute's compliance with constitutional norms in the hands of the legislature.

What Tushnet refers to as "weak form" judicial review is a method of constitutional review that reduces the tension between judicial review and democratic self-governance, while acknowledging that constitutionalism requires some limits on self-governance. ${ }^{21}$ What this means is that weak form review methods act as a check on legislation, giving an opinion as to whether the statute is compliant with constitutional norms. The weak form process acts as a qualified limit on Parliament's sovereignty. It attempts to keep the legislative branch inside their constitutional limits by creating pressure on the legislature to make statutes that conform to constitutional norms. However, what differs with weak form review is that the opinion expressed as to the constitutionality of legislation can always be subjugated by the opinion of parliament, who has the final say in a disagreement about legislation's constitutionality. It is this aspect of the mechanism that creates democratic legitimacy. Tushnet explains three differing types of weak form judicial review procedures.

\section{A Interpretive Mandate}

A 'pure interpretive mandate' centers on a statutory bill of rights that is not entrenched and is not supreme law. ${ }^{22}$ The process can be best understood by looking at the specifics of the procedure in place in New Zealand. The Bill of Rights Act 1990 is an ordinary statute, which in theory could be repealed by a majority at any time. ${ }^{23}$ It lists a number of fundamental individual rights, but what is important is that these rights are not directly enforceable. The act does not let the courts hold legislation as invalid due to a violation of a substantive right. ${ }^{24}$ Instead, where a piece of legislation can be given a meaning

\footnotetext{
${ }^{21}$ Mark Tushnet Weak Courts, Strong Rights: Judicial Review and Social Welfare Rights in Comparative Constitutional Law ( $1^{\text {st }}$ ed, Princeton University Press, Oxfordshire, 2008) at 23.

${ }^{22}$ Mark Tushnet "The Rise of Weak-Form Judicial Review" in Rosalind Dixon and Tom Ginsburg (eds) Comparative Constitutional Law (Cheltenham, Edward Elgar, 2011) at 323.

${ }^{23}$ Tushnet Weak Courts, Strong Rights: Judicial Review and Social Welfare Rights in Comparative Constitutional Law, above n 21, at 25.

${ }^{24}$ Bill of Rights Act 1990, s 4.
} 
consistent with the rights and freedoms listed in the act, then that meaning must be preferred to any other meaning. ${ }^{25}$

How then can this be seen as a weak form of constitutional review? Tushnet explains. When determining what a statutory provision means, a judge begins by using ordinary tools of statutory interpretation, such as the statue's purpose, its legislative history, various cannons of statutory interpretation and so on. ${ }^{26}$ Two possible scenarios can occur. A judge can discover when using the interpretive tools that some tools lead towards a rights protective interpretation and some lead towards a rights restrictive interpretation. Due to the Bill of Rights Act, the interpretive mandate requires the judge to adopt the rights protective mandate. ${ }^{27}$ The second scenario is where nearly all of the interpretive tools point toward the rights restrictive interpretation. ${ }^{28}$ Here is where the clarity of the interpretive mandate as a weak form of judicial review can be seen. Even though parliament has made it reasonably clear as to what their intentions of the statute are, the fact that is it possible to interpret the statute in a more rights protective way will trump the statute's relatively clear purpose. Here, the possible disagreement of the meaning of a statute will result in courts accepting the most rights friendly and constitutional meaning. The fundamental assumption behind weak form judicial review is a reasonable disagreement over the meaning of constitutional provisions. As long as a reasonable rights protective interpretation is possible, this is how the disagreement will prima facie be decided.

Let's say the legislature disagrees with the courts rights protective interpretation. Although it was reasonably possible for the courts to interpret the statute the way they did, let's say it was not how the legislature intended the statute to be read and as a result, the policy that was trying to be put in place has been limited. How then can this conflict be solved? This is where parliamentary sovereignty is seen, the second fundamental aspect of weak form judicial review. A majority in parliament can pass a new piece of legislation, directing the courts as to how to interpret the previously impugned statute. By closing the loophole for a possible interpretation and by instructing the courts as to the

\footnotetext{
${ }^{25}$ Bill of Rights Act 1990, s 6.

26 Tushnet Weak Courts, Strong Rights: Judicial Review and Social Welfare Rights in Comparative Constitutional Law, above n 21, at 25.

27 At 25.

28 Tushnet Weak Courts, Strong Rights: Judicial Review and Social Welfare Rights in Comparative Constitutional Law, above n 21, at 25-26.
} 
exact interpretation intended by parliament, the legislature always has the legal power to end the constitutional disagreement with its own full and final opinion.

\section{B Augmented Interpretive Mandate}

What Tushnet refers to as an 'augmented interpretive mandate' is the current weak form judicial review process that exists in the UK. Basically, it is the same as the New Zealand form of interpretive mandate, with some extra powers held by other government organs. The Human Rights Act $1998^{29}$ (HRA) directs the courts to interpret a statute to be consistent with fundamental rights, just as the pure interpretive mandate does. However, it also give the courts an increased power to declare statutes incompatible with rights stated in the HRA if the courts are unable to interpret legislation in a rights protective manner. ${ }^{30}$ This declaration does not strike down the statute; in fact, it does not have any effects on an individual's legal rights. ${ }^{31}$ What the declaration can do is fast track an amendment process for the impugned legislation, bypassing some of the ordinary procedural obstacles. $^{32}$

This process acts as a weak form of judicial review for all the reasons that a pure interpretive mandate does. It attempts to view legislation in the most constitutionally friendly manner, but also makes an official statement to parliament and the country's citizens when a piece of legislation cannot be interpreted in line with constitutional rights. The declaration states unequivocally that the judiciary disagrees with parliament as to the constitutionality of a piece of legislation. Importantly however, while this may create social and political pressure that parliament must respond to, it does not create any legal consequence that parliament must respond to. Although the judiciary has a disagreement about a piece of legislation's conformity with constitutional norms, its opinion is legally trumped by parliament.

\footnotetext{
${ }^{29}$ Human Rights Act 1998 (UK).

${ }^{30}$ Human Right Act 1998 (UK), s 4.

31 Tushnet Weak Courts, Strong Rights: Judicial Review and Social Welfare Rights in Comparative Constitutional Law, above n 21, at 28.

${ }^{32}$ At 28.
} 


\section{A "Dialogic" Mode of Review}

The last weak form judicial review process stems from the Canadian Charter of Rights. ${ }^{33}$ This form of review gives power to the court to suspend the legal effect of legislation of a statute pending a legislative response through ordinary legislation. ${ }^{34}$ Peter Hogg refers to this type of review as "dialogic" due to the constitutional dialogue that it arguably creates between the judicial and legislative branches of government. ${ }^{35}$

Section 33 of the Charter provides that the Canadian legislature can make statutes effective, for renewable five-year periods, "notwithstanding" their inconsistency with a large number of important charter provisions as interpreted by the court. ${ }^{36}$ Rights such as the freedom of religion, expression, peaceful assembly, life, liberty and justice can all be subjugated if legislation is passed and section 33 is employed to protect the statute's effectiveness notwithstanding a court interpreted charter breach. ${ }^{37}$ There are rights enshrined in the Charter which section 33 cannot apply to, namely democratic rights such as the right to vote and the length of parliament. ${ }^{38}$ This type of constitutional review and its underlying democratic compliance can be explained best with an example. Say a legislature believes, in their opinion, a bill conforms to constitutional principles and it passes it into legislation. The judiciary has a case before them questioning the constitutionality of the piece of legislation and deems it, in their opinion, unconstitutional. What we then have is a classic disagreement between the courts and the legislature about the constitutionality of legislation. With the courts judgment, the impugned statute becomes ineffective, exactly as would occur in the US. However, the legislature is able to pass an ordinary piece of legislation by a simple majority to override the court's decision and make the impugned legislation effective "notwithstanding" the court's opinion as to its unconstitutionality. Over all, the process is one that maximises judicial scrutiny of legislation while still ultimately bowing to democracy.

\footnotetext{
${ }^{33}$ Canada Act 1982 (UK) ch 11, sch B pt I ('Canadian Charter of Rights and Freedoms').

34 Tushnet "The Rise of Weak-Form Judicial Review", above n 22, at 325.

35 Peter W. Hogg and Allison A. Bushell "The Charter Dialogue Between Courts and Legislatures: (Or Perhaps the Charter of Rights Isn't Such a Bad Thing After All)" (1997) 35 OHLJ 75 at 79-81.

36 Tushnet Weak Courts, Strong Rights: Judicial Review and Social Welfare Rights in Comparative Constitutional Law, above n 21, at 31-32.

${ }^{37}$ Canada Act 1982 (UK) ch 11, sch B pt I ('Canadian Charter of Rights and Freedoms') s 33(1).

${ }^{38}$ Above.
} 


\section{Conclusions}

US style judicial review can be said to be unsatisfactory due to the lack of democratic legitimacy. A search for a more democratic process is the entire purpose of this paper. At this point then, hasn't the issue been solved by the above described constitutional review methods of New Zealand, the UK and Canada? Do these methods not fix the legitimacy issue? As explained below, these methods of review, whilst prima facie solving the democratic legitimacy issues, are potentially unstable and may lead to either degeneration into absolute parliamentary sovereignty or the evolution into effective strong form review over time.

\section{Degeneration and Evolution of Weak Form Review}

Sustaining a weak form constitutional review process has been said to be a potentially difficult thing to accomplish. ${ }^{39}$ This difficulty can be explained by looking closer at the above term. A weak form constitutional process is deliberately weaker than strong form review, with the judiciary lacking the final say on constitutional disagreements. However, it is still a process that inquires into the constitutionality of legislation. The problem is that a mechanism may, eventually, evolve into a process which no longer resembles a weak form, or conversely, become so weak that is fails as a constitutional review function entirely.

\section{A Evolution into Effective Strong Form Review}

A weak form system might exist in theory, but in reality operate as a strong form of constitutional review. Such an occurrence would happen when legislatures do not respond to interpretive expansions by the courts or when legislatures routinely adopt judicial proposals to changes in legislation. ${ }^{40}$ Even though the final legal power lies with the legislature due to the structure of the weak form mechanisms, in effect, the legislature's acceptance of the court's ruling on constitutional issues can be said not to be a form of 'judicial dialogue', but instead an acceptance of judicial supremacy in constitutional disagreements. Even though the legislature has the potential to have the final say as to the constitutionality of a piece of legislation, the fact that it doesn't use this power could be construed as deference to the judiciary and an acceptance of their

\footnotetext{
39 Tushnet "The Rise of Weak-Form Judicial Review”, above n 22, at 330.

${ }^{40}$ At 330.
} 
supremacy. This potential problem with weak form judicial review, being that it has the potential to evolve into effective strong form review, can be seen through experiences in Canada and the UK.

\section{Canada}

The federal government of Canada has never invoked the notwithstanding clause. ${ }^{41}$ Such a clause has fallen into desuetude, discredited by its use in Quebec and by threats of use that were never effectively carried out. ${ }^{42}$ Of the mere 16 times the notwithstanding clause has been invoked, 13 of these were in Quebec and were done without public involvement. ${ }^{43}$ There seems to be no evidence of any public debate occurring over these 13 acts, conversely, the public basically ignored the section's use. ${ }^{44}$ In all cases but one, ${ }^{45}$ section 33 has been used preemptively and not as a response to judicial striking down of legislation. ${ }^{46}$ In response to these points, Snow raises a very interesting question, asking: ${ }^{47}$

"If the notwithstanding clause remains a legitimate constitutional instrument, why has it been used so infrequently? In particular, why has it not been used to response to a court ruling with which the government disagrees?"

Asking Snow's question in a slightly different way, can it be that the federal legislature of Canada has never disagreed with the constitutional interpretations of the Courts? Surely this cannot be the case. It would be a difficult argument to make that the legislature reasonably believed that all of the statutes that have been subsequently struck down by the Supreme Court of Canada were unconstitutional. A more reasonable answer to why the federal legislature has not used section 33 in response to court's rulings is because the legislature is deferring to the judiciary in cases of constitutional disagreement. A stronger

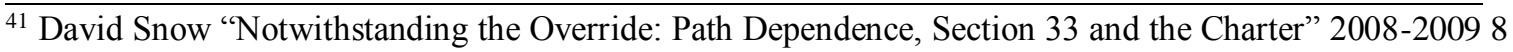
Inovations: A Journal of Politics 1 at 1.

${ }^{42}$ Tushnet "The Rise of Weak-Form Judicial Review", above n 22, at 330.

${ }^{43}$ David Snow "Notwithstanding the Override: Path Dependence, Section 33 and the Charter", above n 41, at 3 .

44 Tsvi Kahana "The Notwithstanding Mechanism and Public Discussion: Lessons from the Ignored Practice of Section 33 of the Charter" (2001) 44-3 Canadian Public Administration 255 at 259-260.

${ }^{45}$ See Ford v Quebec (Attorney General) (1988) 2 (SCR) and Bill 178.

${ }^{46}$ David Snow "Notwithstanding the Override: Path Dependence, Section 33 and the Charter", above n 41, at 3 .

${ }^{47}$ At 4 .
} 
way of saying this is that the legislature is accepting the supremacy of the courts in regards to whether legislation complies with constitutional norms. While the legislature has the power of the final say, the fact that it never uses it cannot be overlooked. What is equally important in a constitutional review process is the reality of the process and not merely the design. Perhaps the answer to this non-use is that the legislature is reserving the power for exceptional circumstances, such as when a judiciary is clearly trying to impose their ideology on the legislature. Returning to the assumptions of Waldron however, the judicial system is assumed to be in good working order with judges existing to reach an impartial decision on a legal dispute. Assuming this is what exits in Canada, it is unlikely that the judges would attempt to impose their particular ideologies through judicial decisions. What is arguably more likely, from the proven lack of use of the notwithstanding clause, is an acceptance of judicial supremacy.

Arguably, while the legal system in Canada is one where parliament has supremacy, the effective system is one where the judiciary has supremacy. If the effective system gives the judiciary the final word of constitutional disagreements, then this looks much more like a strong form of judicial review, rather than the weak form that Canada supposedly has. This shows, in practice, the potential issue that weak form judicial review has; its potential to evolve into effective strong form review and undermine the democratic principles in which weak form review is founded upon.

\section{$2 U K$}

The issue of weak form evolution into effective strong form review can also be seen in examples from the UK. The government in the UK has routinely modified legislation in response to declarations of incompatibility. ${ }^{48}$ Of the 19 declarations of incompatibility that have been made and become final, 18 have been remedied by either changes to primary legislation or remedied by a remedial order. ${ }^{49}$ What this means is that the UK parliament is adopting the opinion of the courts in cases of constitutional disagreement and arguably rubber-stamping the judiciary's decisions. The acceptances of the court's decisions have been described as being done "grudgingly", 50 implying that the legislature

\footnotetext{
${ }^{48}$ Tushnet "The Rise of Weak-Form Judicial Review", above n 22, at 331.

${ }^{49}$ Ministry of Justice (UK) Responding to Human Rights Judgments: Report to the Joint Committee on Human Rights on the Government Response to Human Rights Judgments 2011-12 (September 2012) at 40.

${ }^{50}$ Tushnet "The Rise of Weak-Form Judicial Review", above n 22, at 331.
} 
may have some reservations about the court's constitutional interpretations, but still accepts them despite these reservations.

It is worth noting the court's interpretive mandate that exists along side the court's declaration of incompatibility power. While parliament arguably adopts the court's constitutional opinion from declarations of inconsistency, more difficult is the question of how it responds to rights friendly interpretations of the courts. Where parliament passes legislation to override the rights friendly interpretation the court has used for a specific piece of legislation, then parliament cannot be said to be adopting the courts opinion of legislation's constitutional compliance. The issue is that it is unclear the extent to which this happens, while it is easily observable that parliament is adopting the court's opinion in cases of declarations of inconsistency. One would expect that if a legislature were agreeing with the courts opinion as to constitutional rights violations in cases of declarations of inconsistency, that it would not then act in a way that limits constitutional rights through the narrowing of judge's interpretive abilities. It is odd to suggest that parliament would use one constitutional review instrument to routinely implement the courts opinion and use the other instrument to override the courts opinion. More likely is that parliament accepts the declarations of inconsistency; changing legislation is response and allows the unrestricted use of the interpretive mandate.

If a legislature always accepts the court's final interpretation on constitutional disagreements and passes legislation to make the court's opinion the effective legal response to the constitutional disagreement, can this be said to be the legislature having the final say? The definition of rubber stamp is to, "endorse or approve uncritically; pass routinely or automatically." 51 This definition sounds suspiciously like what the UK parliament is doing with constitutional rights infringements. While it cannot be said that parliament has had no input into constitutional review decisions, due to the fact that it has ignored one declaration of inconsistency, what is apparent is that the courts opinion has been drastically more influential. The adoption of 18 out of 19 declarations of inconsistency cannot simply be overlooked and indicates that the court's opinion is in almost all occasions the one that is followed when legislation's constitutional compliance is at issue. To claim that the judiciary has had the final effective say in a constitutional disagreement would require parliament to adopt the exact critiques of the courts when amending the impugned statutes, which is not the case. But the fact that amendments are made, based on the courts suggestions, suggests that the final decision making of

${ }^{51}$ Lesley Brown The New Shorter Oxford English Dictionary ( $3^{\text {rd }}$ ed, Clarendon Press, Oxford, 1993) Volume 2 at 2641. 
constitutional disagreements is being made by both parliament and the courts, but with the courts opinion having an arguably larger weight.

What this means is that, while parliament has absolute legal sovereignty, the effective nature of how the procedure operates seems to have strong form review characteristics. Unelected judges have a much larger say in the final result of whether a piece of legislation is constitutionally compliant and this seem resemble strong form review rather than a democratically compliant weak form system. While the UK evolution into strong form review can be said to be less than what has occurred in Canada, it again shows the potential for weak form review mechanisms to evolve into effective strong form mechanisms, seen by the reality of how the system works rather than merely looking at the nuts and bolts of the mechanisms make up.

\section{B Degeneration into Absolute Parliamentary Sovereignty}

Of equal concern with weak form judicial review processes is the potential for the process to degenerate into a system of absolute parliamentary sovereignty where, in effect, no review of the constitutionality of legislation takes place. Such a system can be explained by looking at the opposite situations of what has occurred in Canada, the UK and also by looking at New Zealand.

The Canadian notwithstanding clause is rarely ever used, but an equally concerning situation would arise if it was routinely used. Imagine a situation where every piece of legislation passed by the federal legislature had the preemptive protection of section 33 . What this would do is strip any ability the courts have to give their opinion as to the constitutionality of legislation and as a result, there would be no effective constitutional review of legislation. The argument could be made as to why this would be a bad thing. Isn't the point of this paper an attempt to promote democratic principles? If a majority states that the piece of legislation should have the protection of the notwithstanding clause then surely this falls into the realm of the democratic principles that this paper is promoting. The above is true, but must be qualified. Equally important to democratic

principles is that democratic constitutional review actually takes place. By eliminating any form of review whatsoever, the weak form mechanism fails completely and slips into absolute parliamentary sovereignty. While the use of the notwithstanding clause in and of itself does not deserve to be condemned, the consistent use of it to effectively undermine 
any form of judicially based constitutional review shows a potential issue with weak form review.

While it is arguable that the use of section 33 could be seen as parliament engaging in a form of constitutional review itself, constitutional review by the legislature of its own legislation is indistinguishable from parliamentary sovereignty. There is no way to determine whether parliament is saying, "this piece of legislation is constitutionally compliant" or whether parliament is saying, "we are a sovereign legislature and are protecting the effectiveness of this legislation regardless of its constitutional compliance." Instead of answering the question of whether legislation is constitutionally complaint, the use of the notwithstanding clause could equally be parliament ignoring the question entirely and merely expressing its sovereignty. There is no way to determine what parliament is stating by its use of the notwithstanding clause, and therefore there is no way to state with confidence that an engagement of section 33 involves any constitutional review. This would mean that the consistent use of the notwithstanding clause could lead to degeneration into parliamentary sovereignty.

The same issue can be seen if the opposite of the UK situation existed. If out of the 19 declarations of incompatibility, 0 had had any legislative response then it is arguable that no constitutional review function has occurred. In addition, if the legislature consistently overrode rights friendly interpretations reached under the interpretive mandate then it is again arguable that no review function has occurred. By the legislature effectively ignoring every opinion the court has issued as to the constitutionality of legislation, what parliament is arguably saying is that, "all the legislation that we have passed is constitutionally compliant and the opinion of the courts is irrelevant, does not and will not affect our opinion." By ignoring or overriding the courts, the court's opinion becomes redundant and the overall system of constitutional review fails, degenerating into absolute parliamentary sovereignty.

The same situation as described above has the potential to occur in New Zealand. There, the legislature might consistently override rights friendly interpretations reached by the judiciary under the interpretive mandate. If the procedure that allows judges to interpret legislation in line with constitutional norms is constantly subjugated to parliament's interpretive instructions, then what exists can hardly be called a constitutional review process, but rather mere parliamentary sovereignty. 
The three situations described above have not occurred and are unlikely to occur due to political forces. A parliament who constantly overrode or ignored issues relating constitutional rights would not likely keep the confidence of the citizens. However, if the constitutional rights issues only affected minorities, then majorities might not care, or they might in fact agree with the effective lack of constitutional review. The result would be democratic, but more importantly, would destroy any constitutional review function the system had.

\section{Conclusions on Weak Form Review}

At this point, the paper has discussed the need for democratic legitimacy in a constitutional review function and has pointed out that strong form US style judicial review lacks legitimacy. By looking closely at various weak form review mechanisms, it is evident that while these processes maintain democratic legitimacy in theory, they have the potential to degenerate into absolute parliamentary sovereignty or evolve into effective strong form review. After viewing weak form review it is clear the issue has then evolved. The issue has now become creation of a democratic constitutional review function that cannot degenerate into parliamentary sovereignty or evolve into effect strong form review.

\section{$V$ The Executive}

Before dealing with the above stated issue, it is worth pausing and noting a significantly overlooked entity in constitutional review discussion, the executive branch of government. This branch often plays little or no part in a disagreement about a piece of legislation's constitutionality and is said to have been subject to long term neglect in constitutional theory. ${ }^{52}$ Why is this so?

The executive branch of government is democratic. In a Westminster style system, when a political party has the confidence of the House of Representatives, then the leader of that political party is sworn is as Prime Minister. Simply put, the leader of the political party that makes up the majority of the legislature becomes the head of the executive branch. Due to that person having the confidence of the majority of the house, their appointment is democratic. This democratic legitimacy flows to the rest of the executive

52 Terence Daintith and Alan Page The Executive in the Constitution - Structure, Autonomy and Internal Control ( 1st ed, Oxford University Press, Oxford, 1999) at 10. 
government. The executive branch of government in a US style system is equally democratic. In this type of system, citizens vote for their choice of President, who is both the head of state and head of the executive branch of government. Citizens cast their individual votes. These votes decide what presidential candidate the specific states will support. Then, the Electoral College, which is made up of a proportionate number of electors to population per state cast their votes to determine who becomes the president. ${ }^{53}$ Individual citizens votes are indirect, but still result in a democratic election of the president and executive branch of government.

If the executive branch of government is elected democratically, then any decisions that they make in theory should have democratic legitimacy. The traditional position of the executive is that it is supposed to be the branch that merely enforces laws and puts laws into effect. ${ }^{54}$ According to Montesquieu, and his views on the separation of powers, the executive branch should not make laws or settle legal disputes. ${ }^{55}$ However this closedminded and overly theoretical description ignores what modern executives actually do. Modern executives do make law and settle disputes. Taking New Zealand as an example, Ministers and their delegates create and implement regulations frequently. While an Act is created by parliament, the executive branch creates the policies and procedures. ${ }^{56}$ Through power devolved to ministers from parliament, members of the executive routinely create legally binding policies. Also, the executive provides administrative tribunals and authorities that act to settle legal disputes. ${ }^{57}$ Expert members of the executive branch use their knowledge and dispute resolution abilities to reach justified and binding decisions on legal disagreements. Further from this, executives have shown expertise in reviewing and criticising current and future pieces of legislation. Crown entities, such as the New Zealand Law Commission are consistently providing reports critical of current legislation and bills. ${ }^{58}$

\footnotetext{
${ }^{53}$ US Electoral College "What is the Electoral College" $<$ http://www.archives.gov/federalregister/electoral-college/about.html>.

${ }^{54}$ John Adler Constitutional and Administrative Law ( $8^{\text {th }}$ ed, Palgrave Macmillan, East Kilbride, 2011) at 137.

${ }^{55}$ At 137.

${ }^{56}$ See for example Social Security Act 1964 and Work and Income Policy and Procedures.

${ }^{57}$ Ministry of Justice "Tribunals" < http://www.justice.govt.nz/tribunals $>$. List includes, but is not limited to: Accident Compensation Appeals Authority, Alcohol Regulatory and Licensing Authority, Copyright Tribunal, Customs Appeal Authority, Human Rights Review Tribunal, Lawyers and Conveyancers Disciplinary Tribunal, Real Estate Agents Disciplinary Tribunal and Social Security Appeal Authority.

${ }^{58}$ The Law Commission has produced 121 reports critical of legislation.
} 
If an executive is democratically legitimate, practices legislation creation, has experience in dispute settlement and has expertise in the review and critical analysis of legislation, then the issue is raised again as to why it should take no part in the review of legislation's constitutionality. The above facts seem to suggest that the executive branch of government has just as much expertise and an equal mandate to be involved in the review process of legislation. In fact, countries such as New Zealand, Sweden and Japan already involve the executive in the constitutional review process. Executive institutions in these countries screen legislative proposals before they are submitted for legislative consideration in an attempt to ensure constitutional compliance. ${ }^{59}$ The skills required and reasons for constitutional review seem to fit squarely into the modern day reality of what role an executive branch of government performs. Central to this paper is the assumption that the executive is equally justified in taking part in constitutional review and the paper will now make a number of proposals in which the executive plays a central role in constitutional review.

\section{Potential Institutionalisations of the Constitutional Review Process}

The paper now moves on to look at three potential constitutional review models, which attempt to tackle the issue at hand. All three processes are new mechanisms or adaptations of existing constitutional review mechanisms that strive towards a review function that is democratically legitimate and stable in the long term. These three methods can be described briefly as an executive override of judicial decisions, an absolute veto of constitutionally consequential legislation and an executive mandate for judicial intervention.

\section{A Executive Override of Judicial Decisions}

The first of the potential constitutional review models is an adaptation of the US presidential veto power. To provide a better understanding of this potential constitutional review process, it is helpful to firstly understand the veto power, as it currently exists. Within the US Constitution is the power of the President to veto a piece of legislation passed by congress. ${ }^{60}$ Whilst the constitution states that all legislative powers shall be

\footnotetext{
${ }^{59}$ Tushnet, "The Rise of Weak-Form Judicial Review", above n 22, at 322.

${ }^{60}$ US Constitution Art 1, § 7.
} 
vested in the Congress of the United States, ${ }^{61}$ the President is able to subjugate such legislation making power if he or she so chooses. The qualification on this power is that when a president issues a regular veto, he or she returns the unsigned legislation to congress within 10 days, usually with reasons for the veto. Congress can then override the President's decision if it can gain a two-thirds majority in each house. ${ }^{62}$

Instead of focusing on a veto of legislation, as is the focus of the veto power in the US, the proposed constitutional review mechanism would focus on the judiciary's decisions to strike down legislation. The system would exist in a similar fashion to the current US style judicial review. The courts would have the legal power to strike down legislation that, in their opinion, breaches constitutional norms. The addition to the current US constitutional review framework, there would be the creation of the executive power to veto the Supreme Court's decision to strike down a piece of legislation. Put another way, the executive would have the power to make legislation that the court has made unenforceable once again enforceable. If, in the executive's opinion, a piece of legislation that was struck down does in fact comply with constitutional values, the executive would have the power to override the courts decision, render it void and restore the legal effectiveness of the impugned legislation. Although unlikely, the legislature would always have the power to repeal legislation that the president has returned to legal effectiveness if it is of the opinion that the court was correct and the legislation is not constitutionally compliant.

There are two possible variations of this constitutional review process. The first is that the president, after receiving advice from cabinet and other advisors, makes the decision alone of whether the piece of legislation is constitutionally complaint. Under this variation, the democratic election process would give legitimacy to the decision. Because the president has the support of the majority of voters, any decision made by him or her is arguably legitimised by this fact. The second variation of this constitutional review process is that while the formal power rests in the head of the executive, it is exercised after a citizens initiated referendum which reaches a decision on whether a piece of legislation is constitutionally compliant. In this way the individual voters have a direct say in the constitutional compliance of legislation and the democratic result is a decision made by the majority of citizens.

\footnotetext{
${ }^{61}$ US Constitution Art $1, \S 1$.

${ }^{62}$ History, Art and Archives - United States House of Representatives "Presidential Vetoes" <http://history.house.gov/Institution/Presidential-Vetoes/Presidential-Vetoes/>.
} 
For the above reasons, both variations are in line with democratic legitimacy. In regards to stability, issues relating to the non-referendum variant will be discussed in the section below, where the problems of the possible institutionalisations are examined. Looking at the referendum variant however, it is likely that the review function will remain stable. Evolution into strong form review is extremely unlikely. This is because the evolution into strong form relies on parliament, or in this case, on citizens, always agreeing with the decisions of the courts. It is arguable that the consistent agreement with the judiciary occurs because of the political costs of disagreement. Parliament might defer to the judiciary in every case of constitutional disagreement because presenting their own rights limiting opinion might cost votes and have other political effects. Using Canada as an example, the lack of use of section 33 can arguably be reasoned by the political cost of using such a mechanism. The political impact of protecting a rights limiting piece of legislation arguably leads parliament to always respect judicial decisions and never invoke such protection. However, there are no political costs for citizens when presenting their own opinion on legislations constitutional compliance. Because of this, there is no reason why a person would be inclined to always agree with the judicial decisions. It could be said that people trust the opinions of judges more so than legislators and that because of this trust they would be more likely to agree with the opinion of the courts. However, this point misses the crucial issue of consistent agreement. While it may be more likely that citizens will agree with the courts, it is unlikely that citizens will always agree with the courts, due to them having a completely impartial and politically costless choice on constitutional matters. Effective strong form exists due to consistent agreement with judicial decisions, but due to the referendum variant and the lack of political costs attached to individual citizens, it is unlikely consistent judicial agreement would occur.

Furthermore degeneration into absolute parliamentary sovereignty is highly unlikely. This is because, in the absence of any constitutional amendment, parliament's law making power is subject to the constraints of ordinary judicial review. What this means is that parliament is not absolutely sovereign as the judiciary has the power to strike down unconstitutional legislation. The executive, in theory, has the power to grant parliament absolute sovereignty by vetoing all judicial decisions that strike down legislation. However, if the referendum variant is used, it is unlikely that this will occur. The majority of a population is likely to have differing opinions on differing issues. It is a difficult argument to run that in every case of rights issues, citizens would disagree with the courts. Abortion, gay marriage and euthanasia are all good examples of rights issues in which a majority may or may not agree. The likeliness of a population disagreeing 
with all judicial invalidations is low, and therefore so too is the likeliness of this constitutional mechanism degenerating into absolute parliamentary sovereignty.

Executive veto of judicial decisions is the first proposed method of constitutional review. It appears democratically legitimate regardless of which variation is used and is arguable that the referendum variation will be stable and not evolve or degenerate.

\section{Problems with Executive Override of Judicial Decisions}

The executive having the power to override judicial decisions of legislation being inconsistent with constitutional norms is not without problems. The non-referendum variant, where the president alone makes the decision of whether an override should occur, maintains the risk of evolution into effective strong form review. If the executive override is never used, then what is in effect happening is that the judiciary is having the final say on constitutional compliance of legislation. As is the case in Canada, where the federal legislature has the power to protect legislation from being struck down, the nonuse of this power results in effective strong form review. The risk of a case identical to Canada is very real, the only difference being in Canada the power lies with parliament and under this proposal the power lies with the executive. The risk of non-use could equally lead to effective strong form review.

It is unlikely the above problem would exist in the referendum variant due to the fact that the power would not have the same type of non-use risk. As the referendum is a citizen's initiated referendum, it cannot be ignored in the same way that a president or prime minister can ignore the result from a court decision. When a decision of the courts is released, the president would have a chance to respond to it under the non-referendum variant, but there is no direct pressure or mechanism ensuring that the president or prime minster has to respond. For the referendum variant, once the citizens initiates a referendum and gains an answer of whether the judicial decision should be overridden, the president or prime minister must act upon this decision. It is unlikely, but possible, that citizens would never initiate such a referendum and that the power is never used. This would result in effective strong form review. While this is a potential issue of the proposed mechanism, it is arguably less likely to occur under the referendum variant.

Another problem that the executive override has is the specific effect that an override would have on an individual's legal decision from the court. This issue would exist for 
both variants of the proposed mechanism and can best be understood by an example. Say a piece of legislation allows the state to take property for one reason or another. A person brings a case to the judiciary saying the legislation is unconstitutional and they agree, giving judgment in favor of the individual, returning the property and striking down the legislation. The executive decides that the legislation is not unconstitutional, overrides the decision and returns the legislation to legal effect. The issue here is what happens to the individual? If their judgment is reversed, then it is clear that they cannot have their property returned. But the issue is bigger than this and would have systematic effects. Judicial confidence would be severely compromised. The incentive to take a case to court pleading that a piece of legislation is unconstitutional is lessened. After all the time spent and money invested in the judicial process, the executive can come along and simply reverse the decision. Such a fact could result in the constitutional review process failing entirely, as individuals may no longer see the point of bringing constitutional review cases to court if they can simply be overridden. Due to the threat of override, it arguably makes the whole constitutional review process completely pointless.

\section{B Absolute Veto of Constitutionally Consequential Legislation}

The second proposed constitutional review mechanism is another adaptation of the US president's veto power. As explained above, the US president can veto a piece of legislation. This power exists for a number of purposes, one being to ensure that the legislature does not pass legislation contrary to the executive branch's policies. What this adaptation of the veto power would focus on is not ordinary legislation but legislation with constitutional consequences. While the current two thirds majority in both houses would still override a presidential veto in regards to a veto of ordinary legislation, this paper proposes a constitutional review mechanism which holds that if a president vetoes a piece of legislation of constitutional importance, then the legislature is unable to override the veto. The legal consequence would be similar to the current result in the US system where a court strikes down a piece of legislation. Where, in the president's opinion, a piece of legislation breaches constitutional norms, he or she would be able to veto that piece of legislation, making the statute legally ineffective. The mechanism would require what often occurs when presidential vetoes occur; reasons for the veto. If the reason for the veto was the breach of constitutional norms, then that veto of legislation would not be afforded the usual override possibility of a two-thirds majority in congress. Constitutional amendments would likely be deemed to be pieces of legislation of constitutional 
consequence, so while the legislature could pass these pieces of legislation, they would be subject to potential veto by the president's veto power.

The issue of democratic legitimacy is tricky when applied to this potential constitutional review mechanism. This is because we have a conflict between two democratic institutions. The legislature is made up of democratic representatives, but the head of the executive is also democratically elected. On one hand we have a democratic legislature who decides a piece of legislation is constitutionally complaint, and on the other hand we have the democratically elected president or prime minister who states that the legislation is not constitutionally compliant. The current US veto power seems to address this democratic issue by requiring a two-thirds majority vote in the legislature to override the Presidential veto. In this way, the more democratic mechanism trumps the less democratic mechanism. However, both the passing of legislation and the electing of a president or prime minister only require a mere majority. If the executive's decision under the proposed mechanism will trump the legislatures and both institutions are equally democratic, then how can this democratic conflict be resolved? The answer is by simply broadening the scope of what we are comparing. This paper is presenting substitutes for the democratically illegitimate decision making process, judicial review. Placed alongside judicial review, the internal democratic issue can be overlooked. The tension between the executive and legislature doesn't matter, as an executive having the final decision of constitutional compliance is obviously superior to the courts when analysing both mechanisms from a democratic point of view. Because of this, the executive power of an absolute veto of constitutionally consequential legislation can be expressed as having relative democratic legitimacy.

While the opportunity for this review function to degenerate into absolute parliamentary sovereignty exists, it is less likely to occur that the weak form review mechanisms described. Degeneration could potentially occur if the veto power was never used. The mechanism give the head of the executive the power to veto legislation, but creates no obligation on him or her to use such a power when unconstitutional legislation is passed. What differentiates this mechanism from weak form review mechanisms described earlier is the fact that the executive is a political body, while the courts are not. If a court does not react the passing of an unconstitutional piece of legislation, public pressure is of little consequence. The judiciary, being an independent body, has little to no interest in the opinions of average citizens. The executive responds differently to public pressure. Being a political body, public pressure is of much more consequence and pressure being directed towards the executive cannot be so readily ignored. There is no political cost if a 
judiciary refuses to strike down legislation. There is a potential political cost to the executive however if it constantly refuses to use its veto power for legislation that, in the opinion of the public, is unconstitutional. The political backlash is something the executive would likely take into account when deciding whether to veto legislation and due to this potential public pressure it would be unlikely that the veto power would never be exercised.

Evolution into effective strong form review is not possible. Strong form review, being a mechanism where the courts strike down democratically elected pieces of legislation, cannot exist for a very simple reason. The court under this mechanism would not have such a power. Instead, it is the executive who has the power to strike down legislation. While it is arguable that strong form review could be expanded to include any body who has the final power to strike down democratically enacted legislation, what this paper means by strong form review is the judicial review of legislation by democratically illegitimate courts. Accepting this definition, effective evolution into strong form review is not possible.

The function of this mechanism is slightly different from that of the executive override of judicial decisions. Under that proposed mechanism, what occurs is the executive makes valid what would otherwise be invalid legislation. They return legislation to legal effectiveness through the override of the judicial decision that struck down the legislation. Under the absolute veto of constitutionally consequential legislation, the opposite can be said to occur. What occurs under this proposed mechanism is that the executive is making invalid otherwise valid legislation through the use of the veto power. They make legislation legally ineffective. This difference may seem significant, however it is arguably not of any importance. Looking wider at what is occurring under these two constitutional review mechanisms, what we have is simply a mechanism that allows a decision to be made by the executive as to whether a piece of legislation is constitutionally compliant. If the legislation is constitutionally compliant according to the executive, then the legislation is effective. Under the first mechanism, the statute will be returned to legal effectiveness. Under the second mechanism, the veto power will not be used and the legislation will remain effective. If the legislation is not constitutionally compliant according to the executive, then the legislation will be ineffective. Under the first mechanism, the legislation would not returned to legal effectiveness by use of the executive override. Under the second mechanism, the legislation would be vetoed. The difference of whether a power involves invalidation or validation of legislation is arguably irrelevant due to the fact that the use or non-use of both types of powers offers 
the same results when an executive is making a decision about constitutional compliance. In simple terms, non-use of an invalidation power equates to validation and non-use of a validation power equates to invalidation.

\section{Problems with Absolute Veto of Constitutionally Consequential Legislation}

The most obvious issue with this proposed mechanism is what is meant when a piece of legislation is 'constitutionally consequential.' The difference between what is ordinary legislation and what is constitutionally consequential is of great significance as the former can be overridden by the legislature, but the latter cannot. This makes the definition of utmost importance. Such a problem can prima facie be solved quite easily by saying that constitutionally consequential legislation are statutes that affect constitutional norms. This however raises an equally important problem. Who decides whether legislation affects constitutional norms? If it is the President or Prime Minister making this decision, the potential for abuse is enormous. The head of the executive could declare legislation that is in fact ordinary to be constitutionally consequential and use this reason to veto the legislation so that the override power of the legislature is unable to be used. If a President or Prime Minister was going to go to the trouble of vetoing a piece of legislation, it is clear that it is not their intention to have it reenacted by the legislature override. Therefore there is no reason in which the president or prime minister would not state that the legislation was constitutionally consequential, assuming of course this decision was theirs to make. While such a decision of whether legislation is constitutionally consequential could in theory be subject to administrative law, this doctrine relies in a large degree on notions of reasonableness, which is a difficult concept at the best of times.

This proposed mechanism is also limited in the amount of states in which it can be applied to. In a Westminster style state, the head of the political party who has a majority of seats in the legislature is also the head of the executive branch. The "nearly complete fusion of the legislative and executive powers" ${ }^{\prime 63}$ results in an overlap between the legislative making process of a Westminster style state. The issue that exists under this proposed constitutional review mechanism is that the executive is reviewing statutes made by the legislature. Arguably however, stripping away the separation of powers fallacy, the executive is part of the legislature. In a Westminster style state, what would be occurring when the proposed mechanism was being employed would be a review of legislation by the party that made the legislation. Any successful veto would mean a

${ }^{63}$ Walter Bagehot The English Constitution (1 ${ }^{\text {st }}$ ed, Virtue and Co., London, 1867) at 65. 
political party disagreeing with legislation that it passed into law itself. The result is absurd and the only way in which this proposed review function could operate effectively is in a U.S. style system where the executive branch is separate and distinct from the legislative branch.

\section{Executive Mandate for Judicial Intervention}

The final proposed constitutional review mechanism is an adaptation of New Zealand section 7 report procedure. The proposed process can be best understood by first explaining the current reporting procedure under the New Zealand Bill of Rights Act. ${ }^{64}$ Section 7 states that where a bill is introduced into the House of Representatives, the Attorney General shall bring to the attention to the House any provision in the Bill which appears to be inconsistent with any of the rights and freedoms contained in the New Zealand Bill of Rights Act. ${ }^{65}$ Under the Standing Orders of the House, the Attorney general must present a section 7 report as a parliamentary paper and is encouraged to explain why a provision infringes the Bill of Rights. ${ }^{66}$ The report is merely informative and has no legal consequence. Basically, the section demands that the Attorney General asses all Bills and present a report when, in the Attorney General's opinion, a bill is inconsistent with the Bill of Rights Act 1990.

The adaptation that this paper proposes is a combination of this procedure and strong form review. How the mechanism would operate is that before a bill passes into legislation, the bill will be assessed by a specified person within executive branch, in a similar fashion as New Zealand, to determine whether the bill is compliant with constitutional norms. The scope of the inquiry would be greater as all norms of a country's constitutional make up would be assessed, not merely rights declared in a bill of rights. A report would be produced as to the compliance of the bill, indicating whether specific sections and the bill as a whole will be constitutionally compliant if passed into law. In addition to the report, the judiciary would have a US style strong form review power. They would be given the constitutional power to strike down legislation, but would only be able to exercise this power on sections or statutes in which the executive had previously deemed to breach constitutional norms. In the absence of legislation's

\footnotetext{
${ }^{64}$ Bill of Rights Act 1990, s 7.

${ }^{65}$ Bill of Rights Act 1990, s7.

${ }^{66}$ Phillip A Joseph Constitutional and Administrative Law in New Zealand ( $3^{\text {rd }}$ ed, Thomson Brookers, Wellington, 2007) at 1173.
} 
inclusion in a negative report, the judiciary would not have the ability to strike down the legislation and would merely have the power to make a declaration of incompatibility.

The judiciary could choose whether or not to invalidate a piece of legislation if the legislation was included in a negative report. Situations may occur when pieces of legislation affect the constitutional rights of citizens. However, just because a statute or section is included in a negative report doesn't mean it should automatically be struck down. The judiciary still has an important role in the constitutional review process. An inclusion on a negative report means that the executive is of the opinion that the statute or section breaches constitutional norms. But when an individual case is brought to the judiciary, the inquiry isn't that simple. Let's say a statute has the potential to take property rights. In the executive's opinion, this would be unconstitutional and the section is included in a negative report. Let's now say a person has had their property right taken by the legislation. The inquiry is not merely whether the courts think the taking of property rights breaches constitutional norms and if this is so, then the legislation should be struck down. Instead, the court is looking at a fact specific situation, including factors such as rights balancing, the statutory purpose of the legislation, case law, expanding or contracting legal definitions and countless other important legal factors specific to the case presented. While a section may very well deserve to be included in a negative report, it does not mean that any fact scenario brought before the judiciary warrants an invalidation of the legislation. Due to this, the courts role in this constitutional review mechanism is still very important.

The legitimacy of this decision making process has two layers. Prima facie, it appears that such a mechanism would be as democratically illegitimate as regular strong form review. An unelected judiciary is striking down democratically enacted legislation. However, by looking a layer deeper, it is clear that the decision making process does in fact have democratically legitimacy. The judicial striking down of legislation can only be made after a democratic body has made a decision on a pre-enacted piece of legislation's constitutional compliance. In this way, a judiciary cannot be said to be making the decision that the legislation is unconstitutional. What they are in effect doing is agreeing with the democratic decision of the executive and giving that decision legal effect once a specific issue of the legislation comes to existence. Judicial decision-making is democratically illegitimate because the people making such a decision are unelected and not accountable. The executive however is a democratic construct, elected by a majority and accountable to citizens. It is this feature of this constitutional review mechanism that gives the decision-making process legitimacy. 
An executive mandate for judicial intervention is unlikely to degenerate into absolute parliamentary sovereignty. What exists under this proposal is a system where the judiciary has a qualified supremacy. It is the final 'decider' on constitutional disagreements, provided that the executive agrees with such a decision prior. Degeneration could occur if the executive never finds any problems of constitutional compliance within proposed legislation. While this is an ideal situation, it is unlikely to occur. Laws passed by legislatures frequently affect rights and often do so inadvertently. It would be difficult to argue that this would suddenly change by an introduction of the proposed review process. Degeneration could also occur if the judiciary routinely decides to not strike down legislation that has been deemed to be unconstitutional by the executive. Such an event is extremely unlikely. It is difficult to think of a reason in which a court, which has the power to strike down an unconstitutional piece of legislation and has the mandate to do so, would always decide that legislation should stand. Of course, it could be that in the courts opinion all legislation is constitutional or that, as explained above, the fact specific inquiry by the courts does not result in the legislation being deemed unconstitutional. But can this realistically be likely to occur in every constitutional disagreement bought to the courts, especially if the executive is routinely releasing negative reports of legislation's constitutional compliance? One reason why the courts may refuse to strike down unconstitutional legislation is that they do not want to interfere with government policy. They may decide that it is better for them not to strike down legislation due to their lack of expertise in policy creation. This argument however sits on weak foundations. It is the executive that makes policy. If the executive has already indicated in a negative report that legislation is unconstitutional, then surely agreeing with the executive and striking down the legislation is the same as deferring to the executive. How can agreeing with the policy maker be an unreasonable intrusion in policy creation? Degeneration to absolute parliamentary sovereignty would require the courts to ignore issues in which they have the power and the mandate to solve.

Evolution into effective strong form review is not possible under this proposed mechanism. Effective strong form review relies on the judiciary having the effective final say in a constitutional disagreement. This cannot happen with an executive mandate for judicial intervention. Courts are only able to strike down legislation, and present their effective decision on constitutional non-compliance of statutes, when the executive allows them to do so. In the absence of such an allowance, the judiciary has no right to strike down legislation. In this way, the evolution into a system where judiciaries can strike down any unconstitutional piece of legislation is impossible. 


\section{Problems with Executive Mandate of Judicial Intervention}

This proposed constitutional review mechanism has one major issue. The process centers on a report produced by the executive that outlines which sections and bills are constitutionally non-compliant and allow the court the power to strike down these pieces of legislation. But who will produce these reports? In New Zealand, the Attorney General prepares the report that indicates a breach of the Bill of Rights Act. ${ }^{67}$ The Attorney General is a cabinet Minster, but by convention must exercise independent judgment in the public interest. ${ }^{68}$ The Prime Minister appoints cabinet ministers; they themselves are not elected into the position of Attorney General. Therein lies the problem. The ideal review process is one that has democratic legitimacy. Strong form does not fit in this framework due to the fact that the judges of the judiciary who are making the constitutional decisions are not democratically elected. The same issue exists with this review function. It is essentially an unelected person who takes the role of decision maker of whether legislation is constitutionally compliant, the same problem that make strong form review unfavorable.

Giving the report making power to the head of the executive can potentially solve the issue. A democratically elected Prime Minister would not have the appointment issues that face the Attorney General. Unfortunately, the issue is not so easily resolved. Giving the report making power to the Prime Minister in a Westminster system would have the same issues that face the absolute veto of constitutionally consequential legislation. The overlap between the executive and the legislature would undoubtedly result a lack of negative reports. It is difficult to understand why legislation which the majority of parliament wants passed would be placed on a negative report by same political party who wants the legislation to be effective. It is further difficult to understand why the Prime Minister, the head of the majority party in parliament, would push a piece of legislation but give the opportunity for the legislation to be struck down, when it can just as easily take the opportunity to be struck down away by simply omitting it from a negative report. The conflict of interest created between the role of creating legislation and deciding whether legislation is constitutionally compliant has the potential to undermine the constitutional review function if the power is given to a prime minister.

\footnotetext{
${ }^{67}$ Bill of Rights Act 1990, s 7.

${ }^{68}$ Joseph Constitutional and Administrative Law in New Zealand, above n 66, at 242.
} 


\section{The Tyranny of the Majority}

While the above described constitutional review mechanisms prima facie solve the problem of a democratically legitimate review function that is likely to remain stable, they are not without issues of their own. It is useful to take a step back and look at the nature of the review function that is proposed, being one which is founded in democratic principles. The problem described below would apply to all the proposed constitutional review mechanisms.

The main problem of a democratic review function is that it creates the risk of a tyranny of the majority. Although democracy and democratic principles have large benefits for society, the nature of the majority system is that justice for minorities can be prevented when the majority chooses to restrict their rights. ${ }^{69}$ This issue has been raised my many legal philosophers, including James Madison who said, "If a majority be united by a common interest, the rights of the minority will be insecure." 70 The above review proposals, in the forms described, all leave the final decision of constitutional compliance in the hands of the executive. The executive organ is a democratic organ and each of the proposed review functions has the possibility of subverting minority rights for the interest of the majority. With the theory of democracy central to the review function, the risk of a constitutional democracy collapsing into a tyrannical majority is a real possibility.

This risk is one of the major reasons for having strong form judicial review. The power of judicial review has long been associated with the premise that the court stands as a guarantor of rights, protecting political minorities' fundamental freedoms from attacks by the majority elected branches of government. ${ }^{71}$ By imposing one of the proposed mechanisms in place of strong form judicial review, the role of the courts will be changed dramatically by the fact that they will not have a strong form power, and thereby cannot protect minority rights. The tension seems unresolvable. A potential solution will be discussed in section VII of this paper, but for now it seems that either there exists a system that is democratic but risks breaching minority rights or there exists a system that protects minority rights but lacks democratic legitimacy. This fundamental issue prima facie lies within all of the proposed constitutional review functions.

69 Barbara J. Cox ""The Tyranny Of The Majority Is No Myth": Its Dangers For Same-Sex Couples" (2012) 34 Hamline J. Pub. L. \& Pol'y 235 at 243.

70 James Madison "The Federalist No. 51" (1788).

${ }^{71}$ Linda Camp Keith The U.S. Supreme Court and the Judicial Review of Congress: Two Hundred Years in Exercise of the Courts Most Potent Power (1 ${ }^{\text {st }}$ ed, Peter Lang Publishing Inc, New York, 2008) at 117. 


\section{Defence of the Executive Mandate for Judicial Intervention}

None of the proposed constitutional review mechanisms are perfect. However, it is not perfection that is being sought. What is being sought is a democratically legitimate constitutional review function that is likely to remain stable. It is the argument of this paper that the executive mandate for judicial intervention best accomplishes this goal. Before presenting these explanations however, it is useful to take a step back and firstly defend the concept that is being put forward, democratically legitimate constitutional review. The biggest issue with this concept is the risk of the tyranny of the majority, but for reasons stated below, it is clear that this issue is likely overstated and conceptually tenuous.

\section{A Why the Tyranny of the Majority is a Non-Issue}

The concept of the tyranny of the majority is the greatest reason for having strong form judicial review and for taking democratic principles out of the constitutional review process. The supposed risk to the minority is too great when a majority has the power to subvert minority rights. But is this actually the case? While constitutional rights, including minority rights, are essential to any society, it does not follow that anything like strong form review is necessary to preserve constitutional rights. ${ }^{72}$ Looking outside the U.S., where strong form review works to stop the supposed tyranny of the majority, it is pretty clear that constitutional democracies can persist and preserve constitutional rights without strong judicial review or anything like it. ${ }^{73}$ Putting the argument another way, if the tyranny of the majority was such a large risk then surely states that did not have a strong form mechanism to prevent the realisation the risk would be face large majoritarian tyranny and subdued minority rights. It is doubtful whether this exists in reality, where democracies around the world are expanding minority rights, for example, the right to homosexual marriage. ${ }^{74}$ Neither strong form judicial review, nor anything like it is necessary or sufficient to constitutional democracy and while the tyranny of the majority may exist in theory, it is greatly overstated. ${ }^{75}$

\footnotetext{
72 David A. Reid On the Philosophy of Law (1 ${ }^{\text {st }}$ ed, Thomson Wadsworth, Belmont, 2007) at 124.

73 At 124.

74 Marriage Amendment Act 2013 (New Zealand), Civil Marriage Act 2005 (Canada), Marriage (Same Sex Couples) Act 2013 (UK), also democratic legislation passed in Argentina, Belgium, Brazil, Denmark, France, Iceland, Luxembourg, Netherlands, Norway, Portugal, South Africa, Spain, Sweden and Uruguay.

${ }^{75}$ Reid On the Philosophy of Law, above n 72, at 127.
} 
In addition to the reality-based argument sated above, Waldron argues that the common argument of majoritarian tyranny is seriously confused. ${ }^{76}$ We can assume that tyranny is what happens to someone when his or her rights are denied. ${ }^{77}$ The first thing to realise about this definition, according to Waldron, is that potential tyranny is going to be at stake in any disagreement about rights. When a rights disagreement occurs, it is clear that the party in favor of a wider, more expansive understanding of the right will think that the opposite side's position is potentially tyrannical. ${ }^{78}$ For example, defenders of euthanasia rights would think that the position of euthanasia illegality is tyrannical to the sick or elderly wishing to be euthanised. Democratic institutions are not perfect and will sometimes reach and enforce incorrect decisions about rights. ${ }^{79}$ Based on the above definition, they will act tyrannically. But, importantly, so too will courts. A decision made by either organ can deny someone rights and be expressed as tyranny. So then if we accept that both bodies can be potentially tyrannous, what makes tyranny of the majority so bad? Why is a decision aggravated by the fact that a majority imposes it? Put another way; is tyranny by a popular majority (e.g. a majority of elected representative, supported by a majority of his constituents) a particularly egregious form of tyranny ${ }^{80}$ Waldron is unable to see how this is so. His view is that that you can either say tyranny is tyranny, irrespective of how the decision is made or, if how the decision is made is relevant to the question of tyranny, then the fact that it is made through a majoritarian process actually mitigates the tyranny. It does this because there is at least one non-tyrannical thing about the decision, as it was not made in a way that excluded certain people from participation as equals. ${ }^{81}$

Based on these two points, the overstated nature of the tyranny of the majority and the theoretic confusion that the concept has when assessed from a constitutional review basis, the paper argue that the potential threat of tyranny by a democratically legitimate constitutional review mechanism will be of little consequence.

\footnotetext{
76 Waldron, "The Core of the Case Against Judicial Review", above n 8, at 1395.

77 At 1395.

78 At 1395.

79 At 1396.

${ }^{80}$ At 1396.

81 At 1396.
} 


\section{B Resolving the 'Who' Issue}

The biggest issue with the constitutional review function being defended, the executive mandate for judicial intervention, is who will be the person who is preparing the negative reports and how will they attain this position. As stated, the Attorney General would lack the democratic legitimacy required due to his or her undemocratic appointment. While democratic to a degree, as the appointment comes from a democratically elected prime minister or president, this person succumbs to the very same legitimacy issues that face judges. The head of the executive themselves is also arguably not the person to place this power with. The reason why is because, although they fully satisfy the democratic legitimacy requirement of the ideal constitutional review function, their review of the legislation is potentially subject to a conflict of interest. The head of the executive, when preparing these negative reports, will have other concerns that weigh in the decision, the biggest being public policy.

How then can this be resolved? The answer is actually quite simply. A new role can be created, within the executive, where a person's sole job is to fulfill this report-making function. The person would be democratically elected into this position. What would be different with this democratic position compared with a democratically elected judiciary, which would solve all the legitimacy issues of strong form judicial review, is the limited function that this person would have. A judge exists to settle legal disputes across all areas of law. It would be difficult for a person running for a position as judge to state to potential voters his or her stance on the almost infinite legal disputes which he or she would face. This report making position however operates within a much narrower framework. It is much easier for a person running for this position to state his or her position on a limited number of constitutional issues. The smaller amount of potential issues face by this role compared to that of a judge means that democratic election into this type of role is feasible while a democratically elected judiciary is arguably not.

It is helpful to pause at this moment and negate any potential criticisms that may attach to this resolution. The most obvious is how is this person to be elected? The person can be elected merely by the inclusion of the role and candidates in a general election. Alternatively, the role could have a completely separate election. While this may seem like a difficult and costly exercise, that doesn't mean it should not be done. The U.S. is a prime example of this, where their presidential elections are completely separate to the elections of the House of Representatives and the Senate. The presidential election 
system could be said to be a difficult, costly and even an overly complex process. However none of these reasons mean that the method is a bad one.

The creation of this role and the democratic nature that it holds succeeds to a great degree in accomplishing the ideal constitutional review process. The person has a certain level of independence and lack of potential conflict of interests when performing the report making function, meaning that constitutional review element of the process is achieved to the highest degree. The democratic nature of the position means that the decisions this person reaches have legitimacy.

\section{Executive Mandate for Judicial Intervention as the Dominant Proposed Mechanism}

This paper holds that all three proposed forms of constitutional review would accomplish the goal of a democratically legitimate constitutional review function. However, the executive mandate for judicial intervention is the best form proposed. This is so for three reasons; the executive mandate offers a more evenly balanced distribution of constitutional power, it offers a collaborative rather than combative result and is a better potential exercise of the will of the people. These reasons and associated concepts are explained below.

\section{Balanced Distribution of Power}

An executive mandate for judicial intervention takes proposed legislation, reports on whether it is constitutionally compliant, allows the legislation to be passed regardless of what the report says, but allows the future striking down of legislation by the courts if previously subject to a negative report. In short, this approach places the legislative making power in the legislature, an allowance making power in the executive, and a final interpretation power in the courts. Each organ is given power, but is subject to a restriction that stops that power from being supreme. The entire point of constitutionalism, and constitutional review, is to place restrictions on the powers that government organs have to maintain the social contract that the people agreed to at the time a constitution is made. Constitutionalism keeps the government organs from extending their powers to become potentially oppressive. Taking parliamentary sovereignty and judicial supremacy as examples of the two extremes that can be 
potentially reached, it is clear that under either of these two theories, and in the absence of any constitutional amendment, a body exists which has the constitutional power to subject the other organs to its whim. The executive mandate disallows this potential abuse of power, by facilitating power sharing where each branch is responsible to another.

While the executive veto of judicial decisions and absolute veto of constitutionally consequential legislation are good in that they redistribute power traditionally held by the legislature and judiciary, their failure is that they arguably go too far in that distribution. Both of these proposed forms of constitutional review place a full and final decisionmaking power in the hands of the executive. While this paper would argue this is a potentially good thing, due to the democratic nature of the executive, it is arguable that this absolute supremacy held by the executive goes too far in redistributing traditional constitutional review power. Allowing one organ, by itself, to make an unrestricted decision on constitutional compliance can potentially result in the exact type of oppressive behavior that constitutionalism is attempting to combat.

\section{Complimentary Rather Than Combative}

Constitutional review will always involve a tension. On the one hand we have someone relying on a piece of legislation, saying that either the legislation does not in their opinion infringe constitutional values or that it does so but is necessary or reasonable. On the other hand we have another person who is saying that the legislation does infringe constitutional values. The decision of whether the legislation breaches constitutional norms can be made in many ways. At one extreme, parliament could say that no other organ can inquire at all into whether a piece of legislation is consistent with constitutional norms. This is in effect saying that the decision of adherence to constitutional norms will be made only by parliament. At the other extreme, the judiciary can say that any piece of law that affects constitutional norms will be struck down. This is saying that the judiciary can only make the decision of adherence to constitutional norms. In assessing constitutional review as simply a decision and by understanding that the decision can be placed somewhere on a scale between parliamentary sovereignty and judicial supremacy, there are two frameworks in which a constitutional review decision can be seen through.

Firstly, a decision could be combative. What this means is that the government organs are working against each other to try to achieve their respective goals. For parliament this 
will mean the legislation they pass having legal effect and for the judiciary this will mean not enforcing legislation that breaches constitutional norms. Strong form judicial review is a perfect example of a combative constitutional review mechanism, as the judiciary has the final say on whether legislation breaches constitutional norms and whether the legislation will be enforced. It fully considers its own goals and places these before parliaments policy objectives. Absolute parliamentary sovereignty is another example of a combative constitutional review mechanism. There, parliament is not taking the court's opinions into account and merely pursuing with their own legislative interests.

Alternatively, a decision could be complimentary. This type of decision can be best described as falling somewhere in the middle of the scale described earlier. It is neither parliament demonstrating its sovereignty nor the judiciary demonstrating its supremacy, but instead it is a middle ground between the two opposing forces. What this type of decision does is best understood as a form of legislative dialogue. It is the government organs informing the parliament of any constitutional violations that legislation does in a productive way to try to meet a balance between the policy objectives of the legislation and adherence to constitutional norms.

The executive mandate is a perfect example of this arguably superior complimentary constitutional review mechanism. It is a mechanism that operates between parliamentary sovereignty and judicial supremacy with the goal of having constitutionally compliant legislation. It offers the executive to function as a middleman for the tension created between the judiciary and legislature to operate as an informer of legislation's constitutional compliance and strips away the legislature versus judiciary notion traditionally attached to constitutional review. The other two proposed methods of constitutional review unfortunately are likely to be combative forms. The executive override of judicial decisions and absolute veto of constitutionally consequential legislation both result in the executive branch having the full and final say in a constitutional disagreement. Both of these forms create a new doctrine, executive supremacy, and create the exact type of combative tension mentioned above. Because of the nature of an override or a veto, the executive can be said to be working against either the judiciary or parliament in an attempt to achieve its goals. In the same way as strong form judicial review, these methods consider the executive's goals and places them before the goals of either the judiciary or parliament. The executive mandate does not result in the same type of combative constitutional review and for this reason can be said to be more satisfactory that the other two proposed mechanisms. 


\section{An Exercise of the "Will of the People"}

Taking a step back from the specifics of the proposed constitutional review, it is helpful to look at the concept of constitutional review and what it means when a specific constitutional review process is adopted. Any constitutional review process is an attempt to maintain the current constitutional system and norms that citizens have agreed to. It does this by disallowing the legislature to breach constitutional norms when it passes legislation. By creating boundaries for what parliament can legislate on, the initial social contract entered between the people and the state is upheld. For example, constitutional review would likely deem that the abolishment of the judiciary, in a modern democratic state, as unconstitutional. In this way, the people of the nation are saying that the abolishment of the courts is not what they agreed upon when they gave the state the power to govern them. The agreement between people and the state of what powers the state has and how these powers may be exercised is of critical importance when inquiring into issues relating to constitutional review.

As we have seen, constitutional review processes have the potential to evolve into judicial supremacy or degenerate into parliamentary sovereignty. The crucial issue here is that when this evolution or degeneration occurs, it is not done after consultation with the people of the state. What exists is an evolution or degeneration that citizens have not agreed to. While the legal powers themselves are not changed, the effective nature of how the state exercises these powers have changed. What this means is that when degeneration or evolution of constitutional review procedures occurs, we have a power being exercised by the state that was not agreed to by the people. For example, if in the UK declarations of inconsistency were adopted by parliament word for word and wide judicial interpretation were not corrected, we would have the final decision making being made by the courts, where the people agreed that these decisions should not be made by the courts, but they should instead be made by parliament.

Constitutional amendment as a potential remedy for incorrect use of state power always exists, however amendments arguably will not fix the issue. The issue isn't with the power created, but rather with how the organs use the power. Taking the Canadian situation of evolution into effective strong form review as an example, it is difficult to think how a constitutional amendment could result in parliament beginning to use the notwithstanding clause when it is appropriate to do so. Assuming that constitutional amendments cannot return constitutional review procedures which have evolved or degenerated back to the procedure that was originally agreed to by the people, then it 
seem to be that the only way to ensure the social contract is upheld is by having a constitutional review system which cannot, or is at least the most unlikely to, evolve or degenerate. This is again where the executive mandate for judicial intervention dominates the other proposed mechanisms.

The executive mandate for judicial intervention is the least likely mechanism to degenerate or evolve and as a result is the best constitutional review mechanism for maintaining the social contract entered into between people and the state. As stated above in section VI, the role of the courts and the unlikeliness that zero constitutional incompatibilities would be found in proposed legislation means that the chance of degeneration into parliamentary sovereignty is very low. Evolution into strong form is not possible. The other two proposed forms on the other hand place final decision-making power in the executive. As in Canada, there is no way to determine whether they will be used or not. Because of this, the stability of the mechanism is completely reliant on how the procedure will operate in practice. What is attempting to be reached is the creation of a constitutional review mechanism to limit state power, agreed to by the people. However if the state can alter the mechanism through extra legal means, such as non-use of the power, then such a mechanism cannot be said to be satisfactory. Due to the fact that the executive mandate for judicial intervention has the least likely chance to degenerate or evolve, it best satisfies the goal of upholding the constitutional review mechanism agreed to by the people when a social contract was entered into between these people and that state.

\section{Conclusion}

The issue this paper dealt with was the democratic illegitimacy of the US style judicial review procedure. We saw that having unelected judges making decisions that affected individual's constitutional rights was a problem due to the fact that these people were unelected, completely independent and unaccountable. Weak form constitution review, seen through procedures adopted in New Zealand, the UK and Canada, all attempted to solve the democratic illegitimacy issues by setting up respective systems that sees parliament as the final decision maker of constitutional disagreements. However, these systems are not without issues of their own and it was apparent that weak form judicial review mechanisms has the potential to evolve into effective strong form judicial review or degenerate into absolute parliamentary sovereignty. The issue then became how to ensure democratically legitimate constitutional review that would be stable in the long 
term. The paper introduced the executive branch as a possible solution. By proposing three constitutional review processes that held the executive as central importance, the paper attempted to create a constitutional review process that upheld democratic principles and would likely be stable. An executive override of judicial decisions, a executive veto of constitutionally consequential legislation and an executive mandate for judicial intervention where the three proposed mechanisms, each prima facie solving both democratic legitimacy and stability issues with current forms of constitutional review. The executive mandate for judicial intervention was the best proposed mechanism, due to the fact that it best distributed appropriate power between the different government organs, was a mechanism which was inherently complimentary rather than combative and, lastly, was the most likely to respect the will of the people by its stable nature and relative incapability to degenerate or evolve into a system not agreed to by a state's citizens. As the US constitution says, it is the people that should decide how they are governed and the constitutional norms that their society holds. The judiciary having this power is illegitimate and the dominant proposed constitutional review mechanism would return this power to the people. 


\section{Bibliography}

\section{A Cases}

\section{Canada}

Ford v Quebec (Attorney General) (1988) 2 (SCR).

\section{B Legislation}

$1 \quad$ New Zealand

Bill of Rights Act 1990.

Marriage Amendment Act 2013.

2 United Kingdom

Marriage (Same Sex Couples) Act 2013.

Human Rights Act 1998.

\section{Canada}

Canada Act 1982 (UK) ch 11, sch B pt I ('Canadian Charter of Rights and Freedoms').

Civil Marriage Act 2005.

4 U.S.A

US Constitution.

\section{Books and Chapters in Books}

David A. Reid On the Philosophy of Law (1 $1^{\text {st }}$ ed, Thomson Wadsworth, Belmont, 2007).

D. J. Galligan "Judicial Review and Democratic Principles: Two Theories" in Mark Tushnet Bill of Rights (Ashgate, Hampshire, 2007).

John Adler Constitutional and Administrative Law ( $8^{\text {th }}$ ed, Palgrave Macmillan, East Kilbride, 2011). 
Lesley Brown The New Shorter Oxford English Dictionary ( $3^{\text {rd }}$ ed, Clarendon Press, Oxford, 1993) Volume 2.

Linda Camp Keith The U.S. Supreme Court and the Judicial Review of Congress: Two Hundred Years in Exercise of the Courts Most Potent Power ( $1^{\text {st }}$ ed, Peter Lang Publishing Inc, New York, 2008).

Mark Tushnet "The Rise of Weak-Form Judicial Review" in Rosalind Dixon and Tom Ginsburg (eds) Comparative Constitutional Law (Cheltenham, Edward Elgar, 2011).

Mark Tushnet Weak Courts, Strong Rights: Judicial Review and Social Welfare Rights in Comparative Constitutional Law ( $1^{\text {st }}$ ed, Princeton University Press, Oxfordshire, 2008).

Phillip A Joseph Constitutional and Administrative Law in New Zealand ( $3^{\text {rd }}$ ed, Thomson Brookers, Wellington, 2007).

Terence Daintith and Alan Page The Executive in the Constitution - Structure, Autonomy and Internal Control ( 1st ed, Oxford University Press, Oxford, 1999).

Walter Bagehot The English Constitution (1 ${ }^{\text {st }}$ ed, Virtue and Co., London, 1867).

\section{Journal Articles}

Barbara J. Cox ""The Tyranny Of The Majority Is No Myth": Its Dangers For Same-Sex Couples" (2012) 34 Hamline J. Pub. L. \& Pol'y 235.

Daniel Markovits “Democratic Disobedience” (2004-2005) 114 Yale L.J. 1897.

Danielle E. Finck "Judicial Review: The United States Supreme Court Versus the German Constitutional Court” (1997) 20 B.C Int'l \& Comp. L. Rev. 123.

David Snow "Notwithstanding the Override: Path Dependence, Section 33 and the Charter" 2008-2009 8 Inovations: A Journal of Politics 1.

Jeremy Waldron "The Core of the Case Against Judicial Review" (2006) 115 Yale L.J. 1346. 
Mark V. Tushnet “Alternative Forms of Judicial Review” (2005) 101 Georgetown Law Faculty Publications and Other Works 2781.

Peter W. Hogg and Allison A. Bushell "The Charter Dialogue Between Courts and Legislatures: (Or Perhaps the Charter of Rights Isn't Such a Bad Thing After All)" (1997) 35 OHLJ 75.

Tsvi Kahana "The Notwithstanding Mechanism and Public Discussion: Lessons from the Ignored Practice of Section 33 of the Charter" (2001) 44-3 Canadian Public Administration 255.

\section{E Parliamentary and Government Materials}

1 United Kingdom

Ministry of Justice (UK) Responding to Human Rights Judgments: Report to the Joint

Committee on Human Rights on the Government Response to Human Rights Judgments 2011-12 (September 2012).

\section{F Internet Resources}

History, Art and Archives - United States House of Representatives "Presidential Vetoes" <http://history.house.gov/Institution/Presidential-Vetoes/Presidential-Vetoes/>.

Ministry of Justice "Tribunals" < http://www.justice.govt.nz/tribunals>.

US Electoral College "What is the Electoral College" < http://www.archives.gov/federalregister/electoral-college/about.html>.

\section{G Other Resources}

James Madison “The Federalist No. 51” (1788). 


\section{Word count}

The text of this paper (excluding table of contents, footnotes, and bibliography) comprises approximately 14,989 words. 